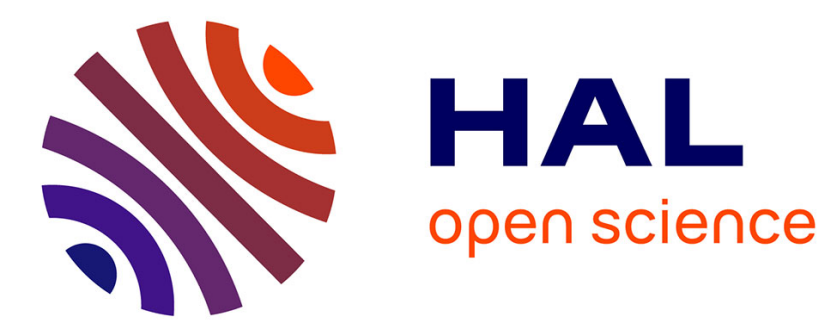

\title{
Universal PCR assays for the differential detection of all Old World species
}

S. Ogado Ceasar Odiwuor, A. Ageed Saad, S. de Doncker, I. Maes, T. Laurent, S. El Safi, M. Mbuchi, P. Büscher, J.-C. Dujardin, G. van Der Auwera

\section{- To cite this version:}

S. Ogado Ceasar Odiwuor, A. Ageed Saad, S. de Doncker, I. Maes, T. Laurent, et al.. Universal PCR assays for the differential detection of all Old World species. European Journal of Clinical Microbiology and Infectious Diseases, 2010, 30 (2), pp.209-218. 10.1007/s10096-010-1071-3 . hal-00630326

\section{HAL Id: hal-00630326 https://hal.science/hal-00630326}

Submitted on 9 Oct 2011

HAL is a multi-disciplinary open access archive for the deposit and dissemination of scientific research documents, whether they are published or not. The documents may come from teaching and research institutions in France or abroad, or from public or private research centers.
L'archive ouverte pluridisciplinaire HAL, est destinée au dépôt et à la diffusion de documents scientifiques de niveau recherche, publiés ou non, émanant des établissements d'enseignement et de recherche français ou étrangers, des laboratoires publics ou privés. 
Title Page

\title{
Universal PCR assays for differential detection of all Old World
}

\section{Leishmania species}

\section{Authors (last name underscored):}

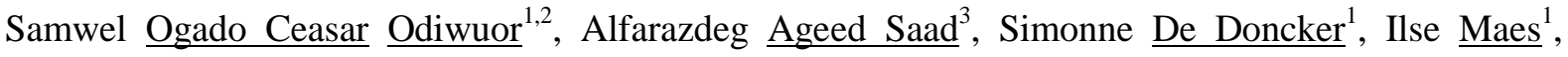
Thierry Laurent ${ }^{4}$, Sayda El Safi ${ }^{3}$, Margaret $\underline{\text { Mbuchi }}^{2}$, Philippe Büscher ${ }^{1}$, Jean-Claude $\underline{\text { Dujardin }}^{1}$, Gert $\underline{\text { Van der Auwera }}^{1}$

\begin{abstract}
Author affiliations:
${ }^{1}$ Institute of Tropical Medicine Antwerp, Antwerp, Belgium; ${ }^{2}$ Center for Clinical Research, Kenya Medical Research Institute, Nairobi, Kenya; ${ }^{3}$ Faculty of Medicine, University of Khartoum, Khartoum, Sudan; ${ }^{4}$ Coris BioConcept, Gembloux, Belgium.
\end{abstract}

Correspondence should be addressed to

Gert Van der Auwera

Department of Parasitology, Institute of Tropical Medicine Antwerp

Nationalestraat 155, 2000 Antwerp, Belgium

Tel. +32 $32476586 \quad$ Fax +32 $32476359 \quad$ e-mail: gvdauwera @itg.be 


\begin{abstract}
Purpose: For epidemiological monitoring and clinical case management of leishmaniasis, determination of the causative Leishmania species gains importance. Current assays for the Old World often suffer from drawbacks in terms of validation on a geographically representative sample set, and ability to recognize all species complexes. We want to contribute to standardized species typing for Old World leishmaniasis.
\end{abstract}

Methods: We determined the ribosomal DNA internal transcribed spacer 1 sequence of 24 strains or isolates, and validated four species-specific PCRs amplifying this target. They discriminate $L$. aethiopica, L. tropica, L. major, and the L. donovani complex, use the same cycling conditions, and include an internal amplification control.

Results: Our PCRs amplify 0.1 pg of Leishmania DNA, while being $100 \%$ specific for species identification on an extensive panel of geographically representative strains and isolates. Similar results were obtained in an endemic reference laboratory in Kenya. Species could also be identified in clinical specimens.

Conclusions: We present validated PCRs to identify all four Old World Leishmania species complexes. These require only agarose gel detection, and have several advantages over existing assays. We outline potential problems, suggest concrete solutions for transferring the technique to other settings, and deliver the proof-of-principle for analyzing clinical samples.

Key words: Old World leishmaniasis; differential diagnosis; Leishmania donovani; Leishmania infantum; Leishmania tropica; Leishmania aethiopica; Leishmania major. 


\section{INTRODUCTION}

Leishmaniasis describes a spectrum of tropical and sub-tropical diseases, which range from self-healing localized cutaneous lesions to aggravated visceral disease with multi-organ involvement, often fatal if left untreated. The diseases are endemic in 88 countries where an estimated 12 million people are infected, while 350 million being at risk [1,2]. The etiological agents are parasites of the kinetoplastid genus Leishmania, in which two subgenera and some 20 medically important species are currently recognized [3]. Leishmania distribution is dichotomized into the Old (East-Africa, the Mediterranean region and the Indian subcontinent) and the New (Central and South-America) World groups. Five species are endemic in the Old World: L. major, L. aethiopica, L. tropica, L. donovani, and $L$. infantum, whereby the latter two comprise the so-called $L$. donovani complex. The distribution of these species is highly dynamic and is expected to be increasingly modulated by global climate changes and associated demographic developments, making species identification on the basis of geographical origin unreliable [4].

Characterization of Leishmania species is important for clinical case management and epidemiological monitoring of the parasite spread [5-7]. Cutaneous leishmaniasis in the Old World can be caused by any of the four following species, each with different disease progression characteristics: L. infantum can also visceralize and cause the lethal visceral leishmaniasis; L. major is often self-curing [8]; L. aethiopica and L. tropica are recalcitrant to treatment $[9,10]$. Visceral leishmaniasis caused by L. donovani in East-Africa often does not respond to first line therapy [11], and is frequently associated with a secondary pathology called post-kala azar dermal leishmaniasis [12]. As species cannot be identified on the basis of morphology and clinical symptoms alone [13, 14], other techniques are needed.

The current gold standard for species discrimination is multi-locus enzyme electrophoresis [15], a cumbersome technique requiring mass parasite cultivation. Molecular methods based upon PCR amplification of a Leishmania DNA fragment have replaced this technique for practical purposes. Many such PCR assays have been reported in literature (reviewed briefly in [16] for the Old World), but they mostly suffer from a lack of validation on all species, fail testing a geographically representative panel of isolates to account for intra-species variability, and are often hampered by 
limited sensitivity. In addition, several assays require post-PCR handlings not always available in endemic regions, such as sequencing, restriction digests or melting curve analysis, required to reveal polymorphisms within the amplified fragment.

The internal transcribed spacer 1 of the ribosomal DNA repeat unit (rDNA-ITS1) has previously been exploited for Old World species discrimination [17] using restriction fragment length polymorphisms [18-20], reverse hybridization assays [21], and melting curve analysis [22]. There are an estimated 20 to 200 identical copies in the Leishmania genome, making it a good target for analyzing low parasite amounts. In this study we describe four species-identification PCRs based on rDNA-ITS1, for discrimination of $L$. aethiopica, L. tropica, L. major and the $L$. donovani complex. We also determined the sequence of this region from 24 isolates or strains.

\section{MATERIALS AND METHODS}

\section{Reference strains}

DNAs from reference strains and isolates were obtained from cultured parasites, and were either grown and extracted at the Institute of Tropical Medicine Antwerp (ITMA, Antwerp, Belgium), or kindly donated by several institutes acknowledged at the end of this manuscript. Concentration of the parasite DNA was measured using the Nanodrop ND-1000 Spectrophotometer (Thermo Scientific, Wilmington, Delaware, USA). Isolates were characterized by rDNA-ITS1 sequencing, or a discriminative PCR targeting cysteine proteinase B [16]. For sequencing, PCR amplicons (Fig. 1) were generated with primers rDNA-10F (5' CAATACAGGTGATCGGACAGG 3') and rDNA-14R (5' CACGGGGATGACACAATAGAG 3'), and this was followed by direct sequencing without cloning. Table 1 lists the origin of all samples used during the evaluation and validation steps, and the accession numbers of the determined rDNA-ITS1 sequences. The definitions of $L$. infantum and $L$. donovani are as in [23].

\section{Primers and internal controls.}

Species-specific PCR primers were designed on the basis of an alignment of rDNA-ITS1 sequences newly determined (Table 1) and downloaded from the EBI sequence data base 
(www.ebi.ac.uk). Several primer combinations per species were tested, and a final set (Fig. 1, Table 2) was selected for extensive optimization, evaluation, and validation experiments. For each of the 4 species-specific PCRs, internal positive control templates were developed (Figs. 2, 3). These internal controls are added to the respective PCRs, and upon successful amplification they show a product of about 100 bp longer than the Leishmania species-specific amplicon. Such internal control allows to check for correct PCR mix set-up, and sample inhibition. To obtain these internal controls, phage lambda DNA fragments were amplified with composite cloning primer pairs, each consisting of a 3' lambda-specific segment with a Leishmania species-specific 5' extension matching the PCR primers in Table 2. The amplified phage lambda sequences were selected to have a base composition comparable to the respective Leishmania targets. The phage lambda amplicons, flanked by the Leishmania primer annealing sites, were cloned in vector pCR4-TOPO using a TOPO TA cloning kit (Invitrogen, Carlsbad, CA, USA), and verified by sequencing (Fig. 2).

\section{Species-specific PCRs}

Five PCRs were used in this study, which are listed in Table 2 and depicted schematically in Fig. 1. The total reaction volume was $25 \mu \mathrm{l}$ of $1 \mathrm{x}$ Coralload PCR buffer (Qiagen, Venlo, The Netherlands), including $0.1 \mathrm{mg} / \mathrm{ml}$ acetylated BSA (Promega, Madison, WI, USA), $200 \mu \mathrm{M}$ of each dNTP supplemented with $400 \mu \mathrm{M}$ of dUTP, in a $200 \mu 1$ tube or plate. Other components are listed in their respective concentration in Table 2, and HotStarTaq Plus DNA polymerase (Qiagen) was used in each case. PCR LT2 was not used in the evaluation and validation experiments. Primers were ordered from Sigma-Aldrich (Bornem, Belgium), dNTPs from Eurogentec (Seraing, Belgium), and dUTPs from Roche (Vilvoorde, Belgium). Cycling conditions for all PCRs were identical: 5 min at $95^{\circ} \mathrm{C}$; followed by 40 cycles of $30 \sec 95^{\circ} \mathrm{C}, 40 \sec 55^{\circ} \mathrm{C}$, and $40 \sec 72^{\circ} \mathrm{C}$; and finally $5 \mathrm{~min}$ at $72^{\circ} \mathrm{C}$. All PCRs were performed in a BioMetra T3000 thermocycler (BioMetra, Göttingen, Germany). Products were analyzed on a $2 \%$ or $2.5 \%$ agarose gel stained with ethidium bromide, and scored positive when an amplicon of the expected size (Table 2) was observed. 


\section{Optimization and Evaluation}

Following development of the PCR protocols, the detection limit of the PCRs was assessed by using 10,1, 0.1, and $0.01 \mathrm{pg}$ DNA from 5 different parasite isolates or strains from each species. This was repeated with the addition of DNA extracted from $9 \mu$ naive human blood in each PCR, for which $2.5 \mu \mathrm{l}$ of $180 \mu \mathrm{l}$ blood extract eluted in $50 \mu \mathrm{l}$ was added to the reaction. The discriminatory power for identifying the correct species was assessed using $100 \mathrm{pg}$ of the DNAs listed in Table 1. The optimal concentration of the recombinant internal control plasmids was determined as the lowest concentration that consistently amplified in repeated experiments, as tested at least in triplicate in a 10 fold dilution series, followed by further refining by using 4 intermediate concentrations. Sensitivity of the internal control amplification to PCR inhibitors was tested by adding $0.01,0.1$, and $1 \%$ of SDS (sodium dodecyl sulphate) to the reaction.

\section{Validation and implementation}

For the purpose of validating the final PCR protocols, a blinded test panel was compiled, including the strains listed in Table 1. DNA from each strain was included twice in the panel: once at an amount of $100 \mathrm{pg}$ per PCR, and once at an amount of $0.2 \mathrm{pg}$ including a DNA equivalent of $1 \mu \mathrm{l}$ naive human blood per PCR. In addition, the panel contained 3 negative controls and 3 naïve blood extracted DNAs as quality check for contamination and cross-reactivity. This makes a total of 90 samples, which were supplemented by 6 negative controls by the person performing the test. Positive results were considered valid if no contamination was observed in these 6 added negative controls, and an amplicon of the expected Leishmania size (Table 2) was obtained. Negative PCR results were valid if no product of the expected size was observed, and the internal control amplicon (Table 2, Fig. 2) was amplified (Fig. 3). In case one of these conditions was not met, the PCR was repeated. All PCR mixes were prepared in bulk, containing all reagents except polymerase and Leishmania template. They were stored at $-20^{\circ} \mathrm{C}$ and when needed an aliquot was taken to which polymerase and template were added. For the purpose of implementation in an endemic reference lab, the tests were transferred to the Kenya Medical Research Institute (KEMRI, Nairobi, Kenya), where PCR mixes 
were produced locally. The tests in KEMRI were performed by a different person as those at ITMA, but using the same blinded test panel DNA.

\section{Clinical samples}

We tested our assays on various clinical samples, containing different species of Leishmania and other pathogens. L. donovani samples were obtained from blood, bone marrow, and lymph node of visceral leishmaniasis patients from Sudan. L. infantum samples were obtained from bone marrow of Italian visceral leishmaniasis patients, and spleen taken from Portuguese dogs suffering of canine leishmaniasis. L. major and L. tropica samples were obtained from skin lesions of cutaneous leishmaniasis patients in Tunisia and Kenya. In addition, our assays were performed on blood from patients suffering Plasmodium falciparum malaria (Uganda) and human African trypanosomiasis (Democratic Republic of Congo), and on sputum from tuberculosis patients (Democratic Republic of Congo). DNA from these samples was extracted using various methods, and the labs acknowledged at the end of this manuscript contributed to the test set.

\section{RESULTS}

\section{Sequences}

The determined rDNA-ITS1 sequences were submitted to the EBI sequence data base, and were assigned accession numbers listed in Table 1.

\section{Optimization and evaluation}

Internal control templates and amplicons were successfully obtained and are depicted in Figs. 2 and 3 . Their amplification was inhibited completely by $0.01 \%$ SDS, indicating their ability to detect PCR inhibitors. All PCRs showed the potential to amplify as little as $0.1 \mathrm{pg}$ of DNA, which is about half a parasite's genome. This detection limit was unaffected by the presence of DNA isolated from human blood, nor by the addition of the internal control template in its proper limiting concentration. For some DNA samples the detection limit was $1 \mathrm{pg}$, for others it was possible to amplify $0.01 \mathrm{pg}$, variations probably caused by DNA degradation. No cross-reactivity of any specific PCR to other 
species was observed during the evaluation phase, except for 1 out of 10 L. aethiopica DNAs that reacted in the LM PCR specific for L. major.

\section{Validation}

Table 3 lists the results of a blinded panel validation, containing at least 10 isolated DNAs of each species or species complex. Results obtained at ITMA are given, as well as those obtained at KEMRI when discordant. In total 6 assays were included in the validation, both using 100 or $0.2 \mathrm{pg}$ parasite DNA, the latter spiked with naïve human blood DNA. The 6 assays comprise the 4 species-

specific assays LA, LDI, LM, and LT1 (Table 2) evaluated separately, but also as a combined tool (5 $5^{\text {th }}$ assay). In the separate evaluation, only the results of one PCR at the time are taken into account (positive or negative), while in the combined assay results from the 4 separate PCRs are considered simultaneously. In the latter case, a species will be assigned only if 1 out of 4 PCRs scores positive, and is listed as undetermined if none or more than 1 PCR shows a positive result. The reason for evaluating the PCRs separately is that in reality it is unlikely that all 4 PCRs are performed on all samples, and more often than not a PCR will be used to confirm only the expected species. Finally, PCR LT2 makes up the $6^{\text {th }}$ assay, which was performed following validation of the other assays because of a poor sensitivity of LT1.

\section{Implementation}

As a proof of principle to assess the performance when using the developed PCRs in another lab, the species-specific PCRs were implemented and validated at KEMRI, a reference lab in Kenya, where leishmaniasis is endemic. Even though the same products and type of thermocycler were used, there was a problem in the amplification of the internal control amplicons, as well as with a slight contamination in the L. donovani complex PCR. This contamination showed a very faint PCR product and was visible in one out of the 6 user-added negative controls but in none of the negative controls of the blinded test panel. When ignoring these faint amplicons, and the fact that in many negative PCRs no internal control amplicon was amplified, the results were almost identical to those obtained at ITMA (Table 3). PCR LT2 (Table 2) was not tested in KEMRI. 


\section{Clinical sample analysis}

Fig. 4 depicts the results of 4 species-specific PCRs in clinical samples. The species could successfully be identified in the various Leishmania samples, as only one of the 4 PCRs showed a Leishmania product of the correct size (Table 2). In all other cases, only the internal control amplicon amplified. In LT2, occasionally a weak PCR product is seen in samples not containing L. tropica, but this product is slightly smaller than $100 \mathrm{bp}$, and clearly below the molecular weight of the product seen in the actual L. tropica samples. Equally so, a very weak amplicon is observed from the LA PCR in the left skin lesion scrapping L. tropica sample, but this is much fainter than the L. tropica amplicon. No products were amplified from patients suffering tuberculosis, sleeping sickness, or malaria.

\section{DISCUSSION}

In this study we present 4 ITS1-rDNA PCRs that can faithfully distinguish the Old World Leishmania species L. aethiopica, L. major, L. tropica, and the L. donovani species complex comprised of $L$. donovani and $L$. infantum. Because the number of sequences available for this region was limited for certain species, we added additional ones to the public repositories (Table 1).

Compared to other assays devoid of post-amplification steps other than agarose gel analysis (reviewed in [16]), our approach has several advantages. (1) First, our assay is universally applicable in the Old World. Intra- and inter-species variability was validated by testing all species from diverse geographical origins (Table 1). It does not allow to differentiate L. infantum from other members of the L. donovani complex, for which alternatives are available [16, 24-26]. (2) Second, the detection limit is sufficient to analyze clinical samples, as between 5 and 1/20 parasite genomes are amplifiable, and we showed amplification in actual clinical samples. (3) Third, our assays include dUTP, which allows to counter the effect of amplicon contamination using the dUTP/UNG system [27]. This can be particularly important in low resource settings, where basic precautions to avoid carry-over contamination are often not easily adhered to, leading to false positive results. (4) Fourth, all 4 assays use the exact same thermal amplification conditions, which allows parallel analysis. As a plus, PCR 
mixes containing all components except Leishmania template and enzyme can be stored at $-20^{\circ} \mathrm{C}$, facilitating batch quality control and saving time. (5) Fifth, internal controls allow checking for consistent amplification across different runs, and PCR sample inhibition [28]. Failure to amplify this control in a negative Leishmania sample points to the presence of inhibitors or an erroneously prepared PCR mix, in which case no conclusions must be drawn from the PCR. In a positive sample, it might simply indicate the Leishmania template outcompetes the control for primer annealing. (6) Finally, as illustrated in Fig. 1, our assays can be used as a nested PCR in case of insufficient sensitivity, whereby the Leishmania-specific primers LITSR and L5.8S [29] generate the outer PCR amplicons. In such case, all 4 specific PCRs must be run in parallel in the second PCR round to ensure specificity.

As can be seen in Table 3, when taking results from the validation PCRs LA, LDI, LM, LT1, and the combined assay, at the $100 \mathrm{pg}$ level the species discrimination and identification performance is $100 \%$, except for L. aethiopica isolate MHOM/ET/67/L86 which cross-reacted in the LT1 PCR. Species identification of this isolate was however based on its unique zymodeme LON33 [30], and the rDNA-ITS1 region (accession FN677356) clearly showed an L. tropica sequence, explaining the positive amplification in the L. tropica PCR. Nevertheless, a limiting amount of L. aethiopica rDNA-ITS1 template is present in the DNA sample, as evidenced by the additional positive L. aethiopica PCR only at the $100 \mathrm{pg}$ level, pointing to a hybrid strain or a mixed culture. The other PCRs showed no cross-reaction at the 0.2 pg level, but some isolates could not be identified. This was the case especially for L. tropica, where only 4 out of 10 DNAs could be typed. Given the fact that amplification failure may be caused by DNA degradation or mismatched primers, it is not surprising that some are not detected at the $0.2 \mathrm{pg}$ level, corresponding to one parasite only. As the L. tropica PCR however identified merely 4 out of 10 L. tropica DNAs when supplied with $0.2 \mathrm{pg}$, we used an alternative PCR (LT2 in Table 2) including an outer Leishmania-specific DNA primer pair (Fig. 1, [29]) to boost the reaction. This allowed an additional 3 L. tropica to be identified from $0.2 \mathrm{pg}$, but resulted in an extra L. aethiopica DNA being detected (Table 3). LT2 must therefore be used only in parallel with PCRs LA, LDI, and LM. 
Upon evaluating the blinded test panel in an endemic reference center in Kenya, two problems were identified: the internal control amplicon did not amplify consistently, and a slight $L$. donovani contamination was observed in one out of six negative controls. Despite using the same products in the PCR mix, this illustrates the necessity to re-optimize the internal control template concentration during implementation. This becomes even more important when changing PCR reagents, such as the type of Taq DNA polymerase. Equally so, depending on the geographical region and type of clinical samples analyzed, one should be aware of potential cross-reactivity against species other than Leishmania. And even though our analysis did not identify cross-reactions against 3 other pathogens, such problems are region and sample dependent, and a validation should be part of any implementation process. In this respect we also highlight that our assays are to be used in second line for Leishmania species identification, only after performing diagnostic - generally more sensitive - assays for parasite detection. During implementation, it is highly recommended to run all 4 PCRs in parallel to assess the performance of each individual PCR by comparing to the combined assay, as was done in Table 3.

Once validated, PCR mixes without DNA polymerase can be prepared in bulk and aliquoted, which allows quality control and saves time. When functioning properly, there is no need to use all 4 PCRs for analyzing each sample (combined assay in Table 3), and one could suffice by using an appropriate selection depending on the exact purpose of the study, and species expected to occur: in endemic settings this would typically be the sympatric species, in travel clinics all species can be found. At most 100 pg Leishmania DNA should be used in the assays, as cross-reactivity for higher concentrations has not been checked for. In clinical samples it is unlikely that a higher amount of Leishmania DNA is present, but if uncertain it is advisable to run all 4 PCRs in parallel to increase the chance of finding unexpected cross-reactions.

Our assays were able to identify the infecting Leishmania species in various clinical samples (Fig. 4), and did not show cross-reaction against Mycobacterium tuberculosis, Plasmodium falciparum, or Trypanosoma brucei. These tests were performed as a proof-of-principle only, as in particular real-life settings the diagnostic specificity and sensitivity must be determined using 
standardized sampling methods, and accounting for the Leishmania species and other pathogens circulating in the region.

Our study presents the first step towards a standardized Old World Leishmania species typing assay. It focuses on validation in cultured samples, with emphasis on implementation of the PCRs in other settings, as a starting point for the use in clinical and epidemiological studies for which the proof-of-principle was delivered. Validation of the PCRs and potential unexpected reactions are essential topics to cover before starting any analysis. We are currently in the process of using the here reported PCRs in endemic reference labs on an extended set of clinical samples, and anticipate that the here described versatile PCRs can contribute to adequate management and follow-up of Old World leishmaniasis.

\section{ACKNOWLEDGEMENTS}

We thank Gabi Schönian (Institut für Mikrobiologie und Hygiene, Berlin, Germany), Henk Schallig and Gerard Schoone (Koninklijk Instituut voor de Tropen, Amsterdam, The Netherlands), and Isabel Mauricio (London School of Tropical Medicine and Hygiene, London, United Kingdom) for contributing DNA from reference strains used in the study. Clinical samples were obtained from (1) Lenea Campino (Institute of Hygiene and Tropical Medicine, Lisbon, Portugal); (2) Luigi Gradoni and Marina Grammicia (Istituto Superiore di Sanità, Rome, Italy); (3) Hechmi Louzir and Afif Ben Salah (Institut Pasteur de Tunis, Tunis, Tunisia); (4) Chantal Van Overmeir, Umberto d'Alessandro, Pim De Rijk, Leen Rigouts, Françoise Portaels, Stijn Deborggraeve, and Philippe Büscher (Institute of Tropical Medicine Antwerp, Antwerp, Belgium). This study was financed by the commission of the European Community's Sixth Framework Program, priority INCO-DEV, project TRYLEIDIAG, contract 015379. SOCO and GVDA are supported by the third framework program of the Belgian Development Cooperation with ITMA.

The authors declare that they have no conflict of interest. 


\section{REFERENCES}

1. Desjeux P (2001) The increase in risk factors for leishmaniasis worldwide. Trans R Soc Trop Med Hyg 95:239-243.

2. World Health Organization (2002) The world health report 2002: Reducing risks, promoting healthy life. World Health Organization, Geneva.

3. Fraga J, Montalvo AM, De Doncker S, Dujardin JC, Van der Auwera G (2010) Phylogeny of Leishmania species based on the heat-shock protein 70 gene. Infect Genet Evol 10:238-245.

4. Ashford RW, Bettini S (1987) Ecology and epidemiology: Old World. In: Peters W, KillickKendrick $\mathrm{R}$ (eds) The leishmaniases in biology and medicine: biology and epidemiology. Academic Press, London, pp 365-424.

5. Reithinger R, Dujardin JC (2007) Molecular diagnosis of leishmaniasis: current status and future applications. J Clin Microbiol 45:21-25.

6. Palumbo E (2009) Current treatment for cutaneous leishmaniasis: a review. Am J Ther 16:178182.

7. Shani-Adir A, Kamil S, Rozenman D, Schwartz E, Ramon M, Zalman L, Nasereddin A, Jaffe CL, Ephros M (2005) Leishmania tropica in northern Israel: a clinical overview of an emerging focus. J Am Acad Dermatol 53:810-815.

8. Morizot G, Delgiudice P, Caumes E, Laffitte E, Marty P, Dupuy A, Sarfati C, Hadj-Rabia S, Darie H, LE Guern AS, Salah AB, Pratlong F, Dedet JP, Grögl M, Buffet PA (2007) Healing of Old World cutaneous leishmaniasis in travelers treated with fluconazole: drug effect or spontaneous evolution? Am J Trop Med Hyg 76:48-52.

9. Modabber F, Buffet PA, Torreele E, Milon G, Croft SL (2007) Consultative meeting to develop a strategy for treatment of cutaneous leishmaniasis. Institute Pasteur, Paris. 13-15 June, 2006. Kinetoplastid Biol Dis 6:3. 
10. Hadighi R, Mohebali M, Boucher P, Hajjaran H, Khamesipour A, Ouellette M (2006) Unresponsiveness to Glucantime treatment in Iranian cutaneous leishmaniasis due to drugresistant Leishmania tropica parasites. PLoS Med 3:e162.

11. Croft SL, Sundar S, Fairlamb AH (2006) Drug resistance in leishmaniasis. Clin Microbiol Rev 19:111-126.

12. Zijlstra EE, Musa AM, Khalil EAG, El Hassan IM, El-Hassan AM (2003) Post-kala-azar dermal leishmaniasis. Lancet Infect Dis 3:87-98.

13. Molyneux DH, Killick-Kendrick R (1987) Morphology, ultrastructure and life cycles. In: Peters W, Killick-Kendrick R (eds) The leishmaniases in biology and medicine: biology and epidemiology. Academic Press, London, pp 121-176.

14. Weiss JB (1995) DNA probes and PCR for diagnosis of parasitic infections. Clin Microbiol Rev 8:113-130.

15. Rioux JA, Lanotte G, Serres E, Pratlong F, Bastien P, Perieres J (1990) Taxonomy of Leishmania. Use of isoenzymes. Suggestions for a new classification. Ann Parasitol Hum Comp $65: 111-125$

16. Laurent T, Van der Auwera G, Hide M, Mertens P, Quispe-Tintaya W, Deborggraeve S, De Doncker S, Leclipteux T, Bañuls AL, Büscher P, Dujardin JC (2009) Identification of Old World Leishmania spp. by specific polymerase chain reaction amplification of cysteine proteinase B genes and rapid dipstick detection. Diagn Microbiol Infect Dis 63:173-181.

17. Schönian G, El Fari M, Lewin S, Schweynoch C, Presber W (2001) Molecular epidemiology and population genetics in Leishmania. Med Microbiol Immunol 190:61-63.

18. Schönian G, Nasereddin A, Dinse N, Schweynoch C, Schallig HD, Presber W, Jaffe CL (2003) PCR diagnosis and characterization of Leishmania in local and imported clinical samples. Diagn Microbiol Infect Dis 47:349-358. 
19. Cupolillo E, Grimaldi G, Momen H, Beverley SM (1995) Intergenic region typing (IRT): a rapid molecular approach to the characterization and evolution of Leishmania. Mol Biochem Parasitol $73: 145-155$

20. Bensoussan E, Nasereddin A, Jonas F, Schnur LF, Jaffe CL (2006) Comparison of PCR assays for diagnosis of cutaneous leishmaniasis. J Clin Microbiol 44:1435-1439.

21. Nasereddin A, Bensoussan-Hermano E, Schönian G, Baneth G, Jaffe CL (2008) Molecular diagnosis of Old World cutaneous leishmaniasis and species identification by use of a reverse line blot hybridization assay. J Clin Microbiol 46:2848-2855.

22. Talmi-Frank D, Nasereddin A, Schnur LF, Schönian G, Özensoy Töz S, Jaffe CL, Baneth G (2010) Detection and identification of Old World Leishmania by high resolution melt analysis. PLoS Negl Trop Dis 4:e581.

23. Lukeš J, Mauricio IL, Schönian G, Dujardin JC, Soteriadou K, Dedet JP, Kuhls K, QuispeTintaya KW, Jirků M, Chocholová E, Haralambous C, Pratlong F, Oborník M, Horák A, Ayala FJ, Miles MA (2007) Evolutionary and geographical history of the Leishmania donovani complex with a revision of current taxonomy. Proc Natl Acad Sci USA 104:9375-9380.

24. Botilde Y, Laurent T, Quispe Tintaya W, Chicharro C, Cañavate C, Cruz I, Kuhls K, Schönian G, Dujardin JC (2006) Comparison of molecular markers for strain typing of Leishmania infantum. Infect Genet Evol 6:440-446.

25. Hide M, Bañuls AL (2006) Species-specific PCR assay for L. infantum / L. donovani discrimination. Acta Trop 100:241-245.

26. Haralambous C, Antoniou M, Pratlong F, Dedet JP, Soteriadou K (2008) Development of a molecular assay specific for the Leishmania donovani complex that discriminates L. donovani / Leishmania infantum zymodemes: a useful tool for typing MON-1. Diagn Microbiol Infect Dis 60:33-42. 
27. Longo MC, Berninger MS, Hartley JL (1990) Use of uracil DNA glycosylase to control carryover contamination in polymerase chain reactions. Gene 93:125-128.

28. Pham DG, Madico GE, Quinn TC, Enzler MJ, Smith TF, Gaydos CA (1998) Use of lambda phage DNA as a hybrid internal control in a PCR-enzyme immunoassay to detect Chlamydia pneumoniae. J Clin Microbiol 36:1919-1922.

29. El Tai NO, Osman OF, El Fari M, Presber W, Schönian G (2000) Genetic heterogeneity of ribosomal internal transcribed spacer in clinical samples of Leishmania donovani spotted on filter paper as revealed by single-strand conformation polymorphisms and sequencing. Trans R Soc Trop Med Hyg 94:575-579.

30. Le Blancq SM, Belehu A, Peters W (1986) Leishmania in the Old World: 3. The distribution of L. aethiopica zymodemes. Trans R Soc Trop Med Hyg 80:360-366. 
Table 1: Origin of strains used for evaluation and validation

\begin{tabular}{|c|c|c|c|c|}
\hline Species & Country & Evaluation $^{\mathrm{a}}$ & Validation $^{\mathrm{a}}$ & Accession numbers $^{b}$ \\
\hline \multirow{5}{*}{ L. aethiopica } & Ethiopia & 8 & 8 & FN677344, FN677347, FN677348, \\
\hline & & & & FN677349, FN677350, FN677351, \\
\hline & & & & FN677352, FN677353, FN677354, \\
\hline & & & & FN677355, FN677356 \\
\hline & Kenya & 2 & 2 & FN677346 \\
\hline \multirow{5}{*}{ L. donovani ${ }^{\mathrm{c}}$} & Ethiopia & 2 & 2 & \\
\hline & India & 2 & & \\
\hline & Kenya & & 1 & FN677363, FN677364 \\
\hline & Sudan & 2 & 3 & FN677358, FN677359, FN677360, \\
\hline & & & & FN677361, FN677362 \\
\hline
\end{tabular}

\begin{tabular}{|c|c|c|c|c|}
\hline \multirow{5}{*}{ L. infantum ${ }^{\mathrm{c}}$} & France & 1 & 1 & \\
\hline & Italy & 1 & 2 & \\
\hline & Malta & & 1 & \\
\hline & Portugal & 1 & & \\
\hline & Spain & 3 & 2 & \\
\hline \multirow{10}{*}{ L. major } & Unknown & 2 & 1 & \\
\hline & Burkina Faso & & 1 & \\
\hline & Israel & 1 & 1 & \\
\hline & Kenya & 1 & 1 & \\
\hline & Saudi Arabia & 1 & 1 & \\
\hline & Spain & 1 & 1 & \\
\hline & Sudan & 1 & 1 & \\
\hline & Tunisia & 1 & 1 & FN677342 \\
\hline & USSR (former Soviet Union) & 1 & 1 & \\
\hline & Uzbekistan & 1 & 1 & FN677357 \\
\hline
\end{tabular}




\begin{tabular}{|c|c|c|c|c|}
\hline \multirow{6}{*}{ L. tropica } & Unknown & & 2 & \\
\hline & Iraq & 1 & 1 & \\
\hline & Israel & 2 & 2 & FN677341 \\
\hline & Kenya & 4 & 2 & \\
\hline & Palestinian territory & 2 & 2 & FN677343, FN677345 \\
\hline & USSR (former Soviet Union) & 1 & 1 & \\
\hline
\end{tabular}

a Where possible, different parasite strains were used for the evaluation and validation.

b Accession numbers are listed according to species and origin, but are not always determined from the strains or isolates used for the evaluation and validation.

c Species of the L. donovani complex (L. donovani and L. infantum) are defined as in [23]. 
Table 2: Overview of species-specific PCRs ${ }^{\text {a }}$

\begin{tabular}{|c|c|c|c|c|c|c|c|c|c|}
\hline PCR & $\begin{array}{c}\text { PCR } \\
\text { specificity }\end{array}$ & $\begin{array}{c}\text { Amplicon } \\
\text { size } \\
\text { Leishmania }^{\mathrm{b}}\end{array}$ & $\begin{array}{l}\text { Internal } \\
\text { control }^{c}\end{array}$ & $\begin{array}{c}\text { Amplicon } \\
\text { size internal } \\
\text { control }\end{array}$ & $\begin{array}{l}\mathrm{MgCl}_{2} \\
(\mathrm{mM})^{\mathrm{d}}\end{array}$ & $\begin{array}{c}\text { Polymerase } \\
\text { (units) }\end{array}$ & & Primers (sequences 5' to $\left.3^{\prime}\right)^{\mathrm{e}}$ & $\begin{array}{l}\text { Concentration } \\
\text { primers }(\mu \mathrm{M})\end{array}$ \\
\hline LA & L. aethiopica & 199 & $\begin{array}{l}\text { pICR1Aet21 } \\
\left(5.61 \times 10^{-8} \mathrm{ng}\right)\end{array}$ & 303 & 2.5 & 0.5 & $\begin{array}{l}\text { rDNA-13F-A } \\
\text { rDNA-18R-A }\end{array}$ & $\begin{array}{l}\text { (AAAATATACAAAACTCGGGC) } \\
\text { (CCGCCAACAAAAGACGG) }\end{array}$ & $\begin{array}{l}0,5 \\
0,5\end{array}$ \\
\hline LDI & $\begin{array}{l}\text { L. donovani } \\
\text { complex }\end{array}$ & 93 & $\begin{array}{l}\text { pICR1Don2 } \\
\left(6.67 \times 10^{-9} \mathrm{ng}\right)\end{array}$ & 220 & 2.5 & 0.5 & $\begin{array}{l}\text { rDNA-1F-DI } \\
\text { rDNA-1R-DI }\end{array}$ & $\begin{array}{l}\text { (AAACATATACAACTCGGGGAGA) } \\
\text { (TTACTGCAAATTTTGAGTACAAAAC) }\end{array}$ & $\begin{array}{l}0,1 \\
0,8\end{array}$ \\
\hline $\mathrm{LM}$ & L. major & 183 & $\begin{array}{l}\text { pICR1Maj10 } \\
\left(5.23 \times 10^{-9} \mathrm{ng}\right)\end{array}$ & 285 & 2 & 0.5 & $\begin{array}{l}\text { rDNA-3F-M } \\
\text { rDNA-11R-M }\end{array}$ & $\begin{array}{l}\text { (CATATACAACTCGGGGAGGCT) } \\
\text { (AAAAACCGAAACGCCGTC) }\end{array}$ & $\begin{array}{l}0,5 \\
0,5\end{array}$ \\
\hline LT1 & L. tropica & 112 & $\begin{array}{l}\text { pICR1Tro45 } \\
\left(5.94 \times 10^{-8} \mathrm{ng}\right)\end{array}$ & 206 & 2.5 & 0.5 & $\begin{array}{l}\text { rDNA-5F-T } \\
\text { rDNA-6R-T }\end{array}$ & $\begin{array}{l}\text { (CAAAACTCGGGGAGGCCTATA) } \\
\text { (ATAASGTCGATCGGCCTTTTG) }\end{array}$ & $\begin{array}{l}0,5 \\
0,5\end{array}$ \\
\hline $\mathrm{LT} 2$ & L. tropica & 112 & $\begin{array}{c}\text { pICR1Tro45 } \\
\left(5.94 \times 10^{-8} \mathrm{ng}\right)\end{array}$ & 206 & 3.0 & 1.0 & $\begin{array}{c}\text { rDNA-5F-T } \\
\text { rDNA-6R-T } \\
\text { LITSR } \\
\text { L5.8S }\end{array}$ & $\begin{array}{l}\text { (CAAAACTCGGGGAGGCCTATA) } \\
\text { (ATAASGTCGATCGGCCTTTTG) } \\
\text { (CTGGATCATTTTCCGATG) } \\
\text { (TGATACCACTTATCGCACTT) }\end{array}$ & $\begin{array}{r}0,5 \\
0,5 \\
0,02 \\
0,02\end{array}$ \\
\hline
\end{tabular}

a Only reagents differing between the PCRs are listed. Common reagents in all PCRs (buffer, BSA, dNTPs, dUTP) are described in Materials and Methods.

b These amplicon sizes can deviate with a few nucleotides depending on the exact strain or isolate. 


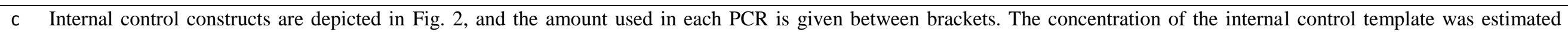
spectrophotometrically using the Nanodrop ND-1000 Spectrophotometer (Thermo Scientific, Wilmington, Delaware, USA).

d This is the final concentration used in the PCR, inclusive of the $1.5 \mathrm{mM}$ already present in the Coralload PCR buffer.

e Primer annealing positions are depicted schematically in Fig. 1. 
Table 3: Overview of blinded panel validation result

Sample type or Leishmania species

\begin{tabular}{|c|c|c|c|c|c|c|}
\hline & \\
\hline & & & & & & \\
\hline & \multirow[b]{2}{*}{ Total number of samples ${ }^{b}$} & \multirow{2}{*}{$\begin{array}{c}\text { L. aethiopica } \\
10\end{array}$} & \multirow{2}{*}{$\begin{array}{c}\begin{array}{c}\text { L. donovani } \\
\text { complex }\end{array} \\
12\end{array}$} & \multirow{2}{*}{$\begin{array}{c}\text { L. major } \\
10\end{array}$} & \multirow{2}{*}{$\begin{array}{c}\text { L. tropica } \\
\\
10\end{array}$} & \multirow{2}{*}{$\begin{array}{c}\text { Negative }^{\text {a }} \\
3\end{array}$} \\
\hline & & & & & & \\
\hline \multirow{7}{*}{$100 \mathrm{pg}$} & $\mathrm{LA} \mathrm{PCR}^{\mathrm{c}}$ & 10 & 0 & 0 & 0 & 0 \\
\hline & LDI PCR ${ }^{c}$ & 0 & 12 & 0 & 0 & 0 \\
\hline & $\mathrm{LM} \mathrm{PCR}^{\mathrm{c}}$ & 0 & 0 & 10 & 0 & 0 \\
\hline & LT1 PCR ${ }^{c}$ & $1^{\mathrm{d}}$ & 0 & 0 & 10 & 0 \\
\hline & Combined assay correct ${ }^{\mathrm{e}}$ & 9 & 12 & 10 & 10 & 0 \\
\hline & Combined assay wrong ${ }^{\mathrm{e}}$ & 0 & 0 & 0 & 0 & 0 \\
\hline & LT2 PCR ${ }^{c, f}$ & 2 & 0 & 0 & 10 & 0 \\
\hline \multirow{7}{*}{$0,2 \mathrm{pg}$} & $\mathrm{LA} \mathrm{PCR}^{\mathrm{c}}$ & $8(9)^{d}$ & 0 & 0 & 0 & 0 \\
\hline & LDI PCR ${ }^{c}$ & 0 & 11 & 0 & 0 & 0 \\
\hline & $\mathrm{LM} \mathrm{PCR}^{\mathrm{c}}$ & 0 & 0 & $8(10)^{d}$ & 0 & 0 \\
\hline & $\mathrm{LT} 1 \mathrm{PCR}^{\mathrm{c}}$ & 1 & 0 & 0 & 4 & 0 \\
\hline & Combined assay correct ${ }^{\mathrm{e}}$ & $8(9)^{d}$ & 11 & $8(10)^{\mathrm{d}}$ & 4 & 0 \\
\hline & Combined assay wrong ${ }^{\mathrm{e}}$ & $1(\text { L. tropica })^{\mathrm{g}}$ & 0 & 0 & 0 & 0 \\
\hline & LT2 PCR ${ }^{c, f}$ & 2 & 0 & 0 & 7 & 0 \\
\hline
\end{tabular}

a Negatives are TE in the $100 \mathrm{pg}$ panel, naïve human blood in the $0.2 \mathrm{pg}$ panel.

b The geographic origin of the isolates and strains is listed in Table 1 .

c See Table 2. For each PCR assay, the number of positive PCRs per species or negative sample type is given.

d When there was no agreement between the numbers for the ITMA and KEMRI validation, the KEMRI result is given between brackets.

e For the combined assay, the number of correctly and wrongly identified isolates from each species is listed, as determined from a parallel evaluation of LA, LDI, LM, and LT1 PCRs.

f The LT2 PCR was not tested in KEMRI, and was not taken into account in the combined assay. 
g The L. aethiopica isolate MHOM/ET/67/L86 was identified as L. tropica. 


\section{FIGURE LEGENDS}

Fig. 1. Position of the sequenced and species-specific PCR fragments relative to the first nucleotide of the $18 \mathrm{~S}$ rDNA gene in chromosome 27 of L. major strain Friedlin (www.ebi.ac.uk, accession number CP000079, release 102), drawn to scale. The 18S, ITS1, and 5.8S rDNA fragments are indicated on top, according to the current annotation. Primers are as in Table 2, and the annealing position of the 5, base is indicated, also delineating the start and end of each amplicon. As the annealing position of all primers is given relative to $L$. major, fragment sizes calculated from these do not correspond to those indicated in Table 2, except for L. major itself.

Fig. 2. Overview of the 4 cloned PCR products used as internal controls (Table 2). These PCR products were cloned in the pCR4-TOPO vector (tools.invitrogen.com/content/sfs/vectors/pcr4topo_map.pdf), from which the cloning site sequence is shown below. Amplicons were inserted using the T:A overhang strategy, and the orientation in the obtained plasmids is as shown in the figure. The internal phage lambda fragments are described in the grey boxes, with positions referring to accession J02459 (www.ebi.ac.uk, accession number J02459, release 102). The regions corresponding to the Leishmania species-specific primer sequences (Table 2) are indicated in the outlined boxes, with the arrows showing the 5'-3' orientation.

Fig. 3. Agarose gel image of the Leishmania species-specific PCR products (L), and the same products with internal control amplicon (IC). The GeneRuler 100 bp DNA size marker (Fermentas, St. Leon-Rot, Germany) is depicted on the left (M), with indicated fragments of 100 (smallest fragment), 500 (brightest fragment), and 1000 (largest fragment) nucleotides. Expected sizes are shown in Table 2.

Fig. 4. Results from 4 species-specific PCRs on clinical samples. The PCRs are indicated on the left, as in Tables 2 and 3. Species in the clinical samples are depicted on top, as well as the type of sample analyzed. Only the agarose gel region between 100 and $400 \mathrm{bp}$ is shown, as indicated by the size marker fragments identified between the left and right gel. The size of the amplified internal control 
and Leishmania fragments is as in Table 2 and Fig. 3, and is respectively indicated by white and black arrows on the right. 